\title{
Rare occurrence of heart lesions in Pacific oysters Crassostrea gigas caused by an unknown bacterial infection
}

\author{
Gary R. Meyer*, Geoffrey J. Lowe, Susan M. Bower \\ Fisheries and Oceans Canada, Science Branch, Pacific Biological Station, Nanaimo, British Columbia V9T 6N7, Canada
}

\begin{abstract}
On rare occasions, small cream-coloured cysts have been observed in the heart and pericardial cavity of Pacific oysters Crassostrea gigas from British Columbia, Canada. Histopathology revealed the presence of large colonies of bacteria (up to $800 \mu \mathrm{m}$ in diameter) causing significant host response and hypertrophy of the heart epithelium. The causative bacteria were characterized as follows: Gram-negative, coccoid to small rod-shaped, typically $<1.5 \mu \mathrm{m}$ in size, cell walls highly endowed with surface fimbriae and division via binary fission. Although these bacteria shared some morphological characteristics with the order Rickettsiales, they did not require an intracellular existence for multiplication. Unfortunately, a cultured isolate was not available, and a retrospective attempt to further characterize the bacteria using DNA sequence analysis of a fragment from the 16S rDNA region proved to be uninformative.
\end{abstract}

KEY WORDS: Pacific oysters $\cdot$ Lesions $\cdot$ Bacteria

\section{INTRODUCTION}

In the fall of 2003, small cream-coloured cysts (up to $1 \mathrm{~mm}$ in diameter) were observed in the heart and pericardial cavity of adult Pacific oysters Crassostrea gigas from 2 locations in British Columbia (BC), Canada. These macroscopic lesions were recorded in approximately $3 \%$ of the oysters examined from both Ladysmith Harbour and Lemmens Inlet ( 1 of 30 and 3 of 120, respectively). Examination of tissue samples via histology and electron microscopy revealed that these cysts were being caused by large colonies of coccoid to short rodshaped bacteria. This paper represents the first report of macroscopic lesions in the heart of C. gigas and describes the pathology and the morphological

\footnotetext{
*Corresponding author: gary.meyer@dfo-mpo.gc.ca
}

characteristics of the bacteria involved with the infection.

\section{MATERIALS AND METHODS}

Histopathology

Transverse cross sections including heart tissue from 120 oysters were preserved in Davidson's solution (Howard et al. 2004) and processed using routine histology techniques for paraffin embedding. Tissue sections were cut at $5 \mu \mathrm{m}$ thickness and stained with haematoxylin and eosin (H\&E). Additional tissue sections from the 4 oysters with lesions were stained using Giemsa and Gram stains ative Commons by Attribution Licence. Use, distribution and reproduction are unrestricted. Authors and original publication must be credited. Publisher: Inter-Research · www.int-res.com 
(Howard et al. 2004). Histology slides were examined and photographed via light microscopy (100x to $1000 \times$ magnification).

\section{Transmission electron microscopy (TEM)}

Heart tissue lesions from 2 oysters were cut into small pieces (2 to $3 \mathrm{~mm}$ cubes), preserved in $2.5 \%$ gluteraldehyde in Sorenson's phosphate buffer $(\mathrm{pH}$ 7.2) and stored at $4^{\circ} \mathrm{C}$ for 12 to $25 \mathrm{~d}$. Tissues were rinsed $3 \times$ with the same buffer, post fixed for $2 \mathrm{~h}$ in $1 \%$ osmium tetroxide, rinsed another $3 \times$ with buffer, dehydrated through an ethanol series and acetone followed by infiltration and embedding in epoxy resin (Eponate 12 kit Marivac). Thin sections were mounted on grids, stained with uranyl acetate and lead citrate and examined using a Zeiss EM 10 transmission electron microscope.

\section{Polymerase chain reaction (PCR) and sequencing}

Small pieces of heart tissue containing lesions were preserved and stored in 95\% ethanol for approximately 12 yr. Recently, DNA from 1 sample was extracted using a DNeasy tissue Kit (Qiagen) according to the manufacturer's instructions. The extracted DNA concentration and purity was measured using a Nanodrop spectrophotometer (166 ng $\mathrm{\mu l}^{-1}$ ). A PCR assay was conducted using a previously published primer pair (968f and 1401r) designed to amplify bacterial $16 \mathrm{~S}$ ribosomal DNA (Nübel et al. 1996). The PCR reaction was performed using HotStar Taq (Qiagen) with $1 \mu$ of undiluted DNA as template in a $25 \mu \mathrm{l}$ reaction volume with final concentrations of the following: $1 \times$ buffer, $5 \times$ Q-Solution, $3 \mathrm{mM} \mathrm{MgCl}_{2}, 0.2 \mathrm{mM}$ dNTPs, $0.1 \mu \mathrm{M}$ forward and reverse primer and $0.05 \mathrm{U} \mu \mathrm{l}^{-1}$ of Taq polymerase. The thermal cycling conditions were $5 \mathrm{~min}$ at $95^{\circ} \mathrm{C} ; 40$ cycles of $30 \mathrm{~s}$ at $95^{\circ} \mathrm{C}, 30 \mathrm{~s}$ at $55^{\circ} \mathrm{C}$ and $30 \mathrm{~s}$ at $72^{\circ} \mathrm{C}$; followed by a final cycle of $10 \mathrm{~min}$ at $72^{\circ} \mathrm{C}$. The PCR product was visualized on $1.5 \%$ agarose gels stained with SYBR Safe (Thermofisher) and then purified for sequencing using EXOSap-IT (USB Corporation). The sequencing reaction was carried out using Big Dye Terminator v3.1 (Thermofisher) with $1 \mu \mathrm{l}$ of purified PCR product as template, according to the manufacturer's protocol; the products were then purified using the DyeEX 2.0 Spin Kit (Qiagen) and run on an ABI 3130xl genetic analyzer.

\section{RESULTS}

\section{Histopathology}

The bacterial colonies occurred primarily in the heart, but in 2 of 4 specimens were also observed to a lesser degree in the connective tissue of the mantle, gills, labial palps and digestive gland. The colonies consisted of bacteria that were weakly basophilic with H\&E (Figs. 1 \& 3), strongly basophilic with Giemsa stain (Fig. 2) and Gram negative (Fig. 4). The size of the colonies ranged from 10 to $800 \mu \mathrm{m}$ in diameter and caused hypertrophy of the heart epithelium (Fig. 1). Smaller colonies $(<200 \mu$ m diameter) were usually spherical and appeared to be contained by the host (Fig. 4). Larger colonies were often irregularly shaped and associated with host responses consisting of haemocyte infiltration (Fig. 3).

\section{TEM}

The bacterial colonies were usually contained within a cyst wall (Figs. 5-7), which consisted of amorphous material and sometimes incorporated remnants of degenerating cells and elongated muscle fibres (Fig. 5). In addition to numerous bacteria, the cysts contained haemocytes, which were often located along the internal surface of the cyst wall (Figs. 5-7). Some of these haemocytes were necrotic, but others contained necrotic-looking bacterial cells within phagosomes (Fig. 5). Phagocytosis by host haemocytes was commonly observed (Figs. 5 \& 6). However, the colonies did not appear to have an intracellular habitat, and bacteria were observed to multiply within the cyst matrix (Figs. 9-11). Some cysts also contained disrupted striated heart muscle fibres, usually with closely associated bacteria (Figs. 7, 8 \& 11). The bacteria were predominantly coccoid and short rod-shaped; however, a few pleomorphic specimens were also observed (Figs. 5-11). Individual bacteria measured from 0.32 to $0.65 \mu \mathrm{m}$ in diameter and up to $1.75 \mu \mathrm{m}$ in length $(\mathrm{n}=78)$, and division by binary fission was commonly observed (Figs. 9-11). All bacteria were highly endowed with surface fimbriae (filaments or pili) (Figs. 8-11). The interior of most bacteria was formed by granular electron-dense material which often had a mottled appearance, the density of which increased substantially near the outer membrane. An electrondense cap was also observed in some specimens (Figs. 9 \& 11). 


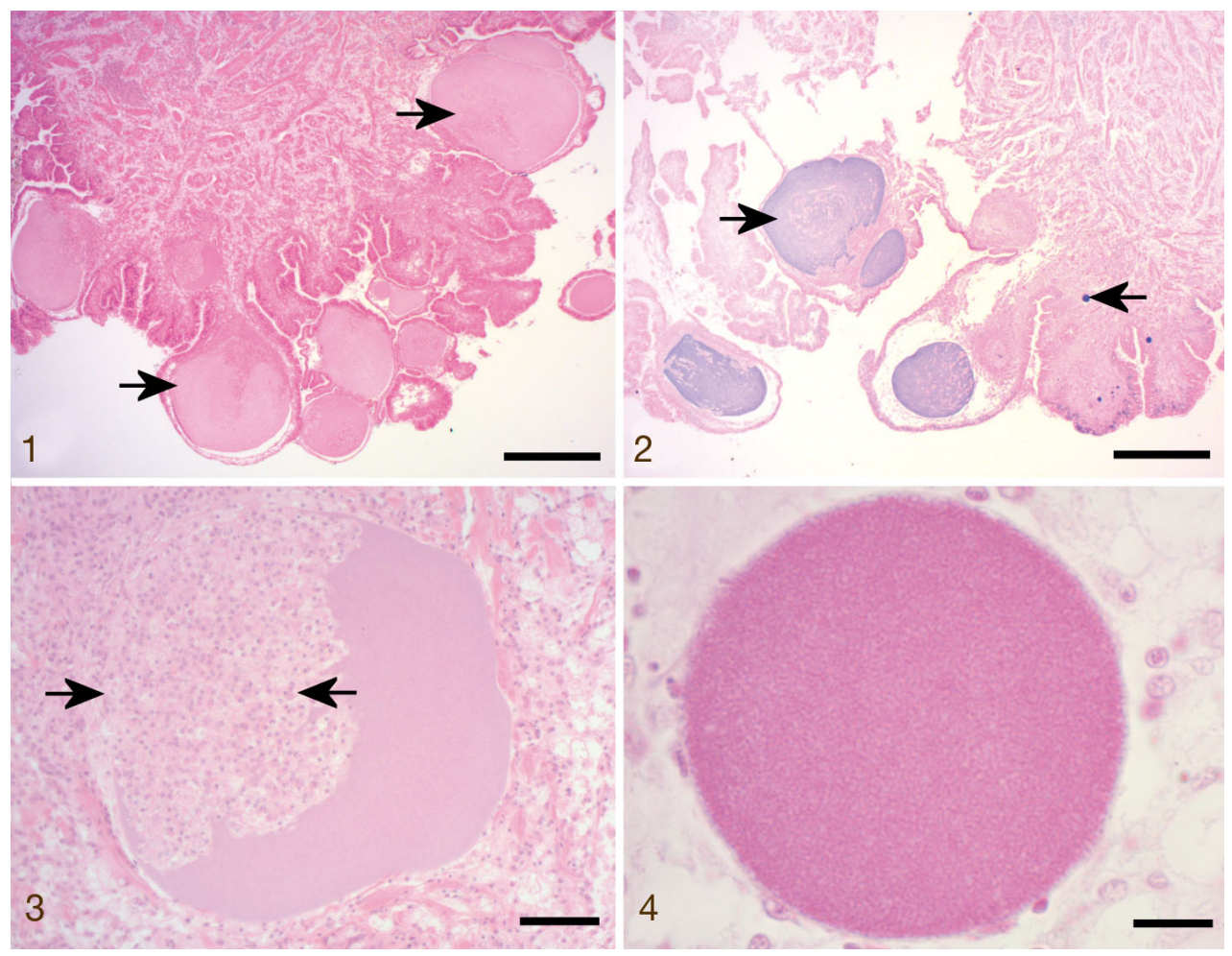

Figs. 1 to 4. Histological tissue sections of Crassostrea gigas heart tissue showing lesions caused by large bacterial colonies. Fig. 1. Low magnification showing multiple large colonies of bacteria (arrows) causing hypertrophy of the heart epithelium $\overline{(H \& E}$ stain, scale bar $=500 \mu \mathrm{m})$. Fig. 2. Low magnification showing multiple colonies of bacteria (arrows) ranging from 10 to $800 \mu \mathrm{m}$ in diameter (Giemsa stain, scale bar $=500 \mu \mathrm{m}$ ). Fig. 3. Close up of a ruptured bacterial colony which has elicited host response (arrows) consisting of abundant haemocyte infiltration (H\&E stain, scale bar $=50 \mu \mathrm{m})$. Fig. 4. High magnification showing a single discrete bacterial colony which appears to be contained by the host (Gram stain, scale bar $=10 \mu \mathrm{m}$ )

\section{Sequence analysis}

A 403 bp sequence fragment from the $16 \mathrm{~S}$ rDNA region was obtained from a single sample (GenBank accession no. KY799077) with BLAST results identifying most closely with uncultured bacteria from multiple origins (the top 50 results showing 93 to $95 \%$ similarity over the entire fragment).

\section{DISCUSSION}

The histopathology and morphological characteristics of the bacteria observed between specimens from both locations were identical, suggesting that a common agent was responsible for the lesions. Examination by electron microscopy revealed that the bacteria possessed abundant fimbriae, a common feature among other Gram-negative pathogenic bacteria (Cheville 1994). Some of the bacteria appeared to be closely associated with heart muscle fragments within the cysts, presumably the result of rupture and dissociation of the heart muscle by large bacterial colonies.
Although the characteristics of the bacteria reported in this study somewhat resemble those described for the order Rickettsiales (Weiss \& Moulder 1984, Cheville 1994), they appeared to lack the obligate intracellular tropism which is a defining characteristic of this group. Rickettsiales-like prokaryote organisms (commonly referred to as RLP or RLO) have been reported from $>25$ species of bivalve molluscs over a wide geographic distribution (for example, see Harshbarger et al. 1977, Elston \& Peacock 1984, Elston 1986, Fries \& Grant 1991, Sun \& Wu 2004, Bower 2010). These RLP infections typically occur in the epithelial cells of the gills or digestive gland and in most instances are considered to be benign; only in rare cases have they been implicated with disease and mortality among bivalves.

Unfortunately, little is known about the biochemical or growth characteristics of the oyster heart bacteria because isolation and culture was not attempted at the time of necropsy in 2004 and because subsequent occurrence of heart lesions in $\mathrm{BC}$ oysters has been extremely rare $(<0.5 \%)$. Also, the attempt to gain more insight into the identity 

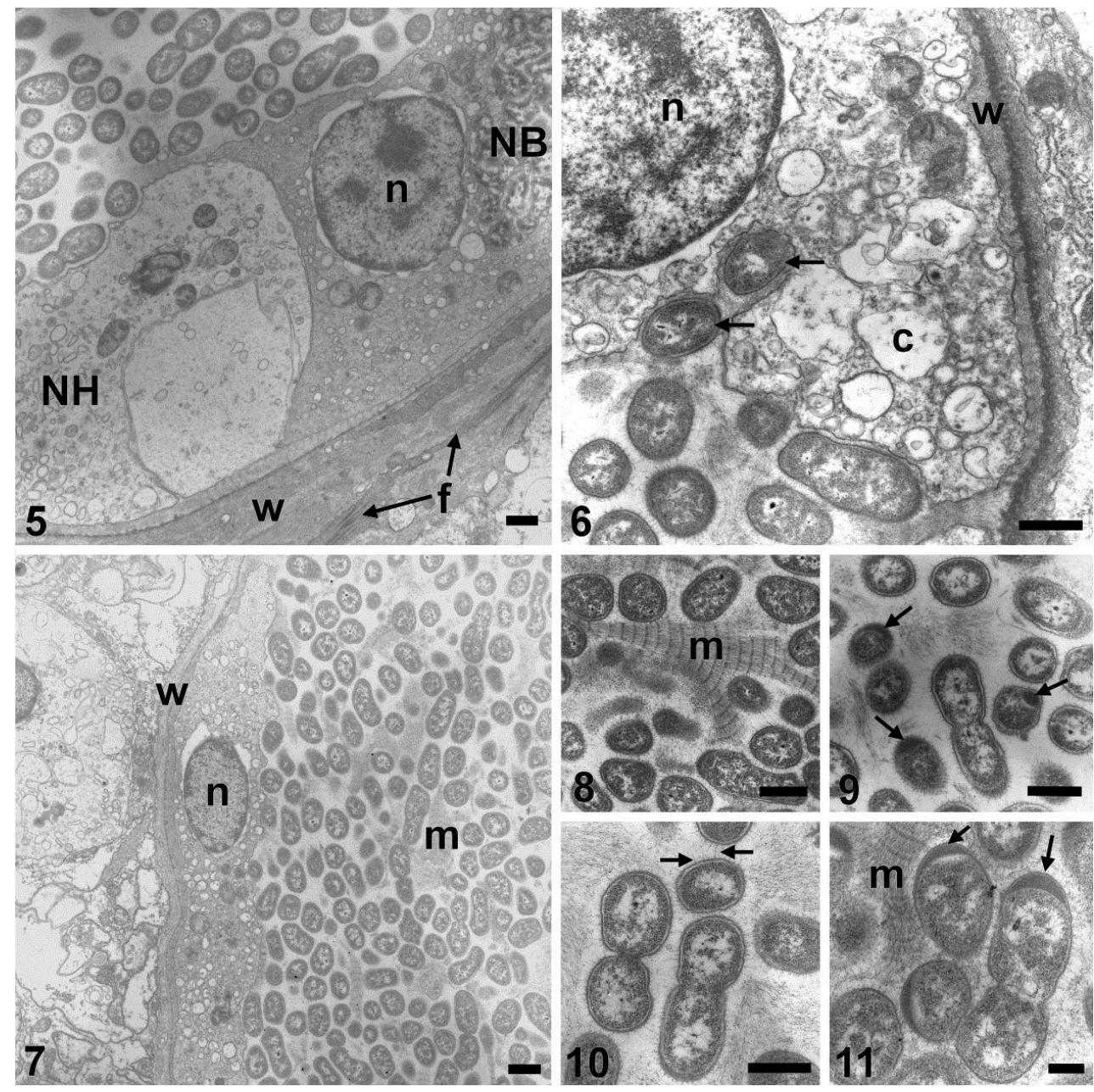

Figs. 5 to 11. Transmission electron micrographs. Fig. 5. Two haemocytes, one of which appears necrotic (NH) located on the interior of the cyst wall (w) that incorporated cell remnants and elongated muscle fibres (f). The healthy looking haemocyte contains many necrotic-looking bacteria (NB) within a phagosome adjacent to its nucleus (n). Scale bar $=0.5 \mu \mathrm{m}$. Fig. 6 . Two bacteria (arrows) being phagocytized by a host haemocyte sectioned through its nucleus (n) and cytoplasmic vacuoles (c). The haemocyte is adjacent to the cyst wall (w). Scale bar $=0.5 \mu \mathrm{m}$. Fig. 7 . An elongate haemocyte (n) containing a few phagocytized bacteria is stretched along the interior surface of the cyst wall (w); numerous bacteria and heart muscle (m) fragments are also present within the cyst. Scale bar $=1.0 \mu \mathrm{m}$. Fig. 8. Numerous bacteria closely associated with striated muscle (m) of the heart. Scale bar $=0.5 \mu \mathrm{m}$. Fig. 9. Three bacteria with electron-dense caps (arrows) surrounding an example of a bacteria undergoing binary fission. Scale bar $=0.5 \mu \mathrm{m}$. Fig. 10. Abundant fimbriae (arrows) protruding from the outer surface of the bacteria cell walls. The 2 bacteria in the central portion of the image are in the process of binary fission: (right) in early stage division showing invagination of the cell wall, and (left) exhibiting late-stage division and about to pinch off to form separate daughter cells. Fig. 11. Several bacteria with electron-dense caps (arrows), one of which is in the early stages of cell division.

Fragments of heart muscle $(\mathrm{m})$ located near the bacteria. Scale bar $=0.25 \mu \mathrm{m}$

of the bacteria via sequence analysis of a $16 \mathrm{~S}$ rDNA fragment proved to be uninformative. Considering the complex nature of bacterial taxonomy and the lack of conclusive evidence supporting specific taxonomic affinities to the Rickettsiales, it was decided at this time to refer to the causative microorganisms simply as unknown bacteria. Nonetheless, this report documents new findings concerning lesions in the heart of Pacific oysters that are caused by a bacterial infection. Although these lesions are a rather sporadic and rare phenomenon in $\mathrm{BC}$, further research and identification of these bacteria is warranted given that C. gigas is an economically important species that is cultivated in many parts of the world.

Acknowledgements. This study was financially supported by Fisheries and Oceans Canada. 


\section{LITERATURE CITED}

Bower SM (2010) Synopsis of infectious diseases and parasites of commercially exploited shellfish. Fisheries and Oceans Canada, www.dfo-mpo.gc.ca/science/aah-saa/ diseases-maladies/index-eng.html (accessed 08 February 2017)

Cheville NF (1994) Cytopathology of pathogenic prokaryotes. In: Cheville NF (ed) Ultrastructural pathology an introduction to interpretation, Chap 12. Iowa State University Press, Ames, IA, p 616-710

Elston RA (1986) Occurrence of branchial rickettsiales-like infection in two bivalve molluscs, Tapes japonica and Patinopecten yessoensis, with comments on their significance. J Fish Dis 9:69-71

Elston RA, Peacock MG (1984) A rickettsiales-like infection in the Pacific razor clam, Siliqua patula. J Invertebr Pathol 44:84-96

Fries CR, Grant DM (1991) Rickettsiae in gill epithelial cells of the hard clam, Mercenaria mercenaria. J Invertebr

Editorial responsibility: Kimberly Reece,

Gloucester Point, Virginia, USA
Pathol 57:166-171

Harshbarger JC, Chang SC, Otto SV (1977) Chlamydiae (with phages), mycoplasmas, and rickettsia in Chesapeake Bay bivalves. Science 196:666-668

Howard DW, Lewis EJ, Keller BJ, Smith CS (2004) Histological techniques for marine bivalve molluscs and crustaceans. NOAA Tech Memo NOS NCCOS 5

Nübel U, Engelen B, Felske A, Snaidr J and others (1996) Sequence heterogeneities of genes encoding 16S rRNAs in Paenibacillus polymyxa detected by temperature gradient gel electrophoresis. J Bacteriol 178: $5636-5643$

Sun J, Wu X (2004) Histology, ultrastructure and morphogenesis of a rickettsia-like organism causing disease in the oyster, Crassostrea ariakensis Gould. J Invertebr Pathol 86:77-86

Weiss E, Moulder JW (1984) Section 9. The Rickettsias and Chlamydias. In: Frieg NR, Holt JG (eds) Bergey's manual of systematic bacteriology, Vol 1. Williams \& Wilkins, Baltimore, MD, p 687-739

Submitted: March 27, 2017; Accepted: July 3, 2017 Proofs received from author(s): August 11, 2017 